\title{
NOTE ON THE BRITISH SPECIES OF ANOMIA.
}

\section{By R. Winckworth, M.A.}

Read 9th November, 1921.

(PLATE I.)

THE object of the present note is to emphasize the distinctions between the four British species of Anomiidæ. There is nothing new in this; Forbes and Hanley recognize four species, though squamula is placed with ephippium instead of with aculeata; abroad, Dautzenburg and Jensen among others distinguish them conchologically. Ridewocd in Phil. Trans., vol. 195, 1903, describes the gill of $A$. aculeata and places this species with Dimya in a separate suborder Dimyacea (l.c., p. 185): he also figures $A$. ephippium and A. laqueata, the latter similar to patelliformis.

I have recently examined numerous examples of this group from Plymouth Marine Biological Association and elsewhere. All the species are very variable in shape, thickness, and sculpture: and the young of all four are discouragingly similar in appearance, while the muscular scars are often very faint in small examples; so that the soft parts and above all the gill are a valuable aid to identification. There is no need to section the gill or even to use a microscope; a good lens will at once show sufficient to determine the species, as summarized below.

\section{ANOMIACEA. ANomirda. \\ Genus ANOMIA, L., 1758. Type, A. ephippium, L.}

1. EPHIPPIUM, L., 1758. Upper or left valve with three distinct muscular scars (Pl. I, f. 8). Gill W-shaped in section, and at once recognizable by a dependent membranous flap of the outer ascending lamella, the fifth lamella of Lacaze Duthiers (P]. I, f. 1).

Genus MONIA, Gray, 1849. Type, A. zelandica, Gray, in Dieffenbach, 1843.

I do not like referring British species to a New Zealand genus, but as I have only seen the shell of zelandica, and can see no conchological reason for not including our species under the same genus, I must at present leave the two following species here.

2. PATELliformis, L., 1761. The original description in Fauna Svecica is not quite satisfactory, and suggests the next species, but the figure given in N. Act. Upsala 1773 confirms the usually accepted identification, and in each case the species is mentioned as received from A. R. Martin. Hanley states that the types in the Linnean cabinet were introduced by the younger Linné.

Upper valve with two muscular scars, which are separate and distinct (Pl. I, f. 9). The typical sculpture may be almost obsolete, and, indeed, is quite absent in very young examples, or may be 
exaggerated into prickles. Gill, W-shaped, without the fifth lamella of flap of ephippium (Pl. I, f. 2). Further, in addition to the row of ciliated discs at the lower angles of the lamellæ; which are found also in Anomia, there are in Monia other intermediate rows of ciliated discs along the faces of the filaments. In this species there is one of these in the outer and two in the inner lamella.

3. squama, Gmelin, $1791=A$. striata, Lovén, non Bolten $=$ A. glauca, Monterosato. Gmelin's species is based on Chemnitz, viii, 697, where the figure is recognizable and the description unmistakable, locality Drontheim. In this species the shell adductor immediately adjoins the byssal muscle on the left side of the animal, so that the two form one continuous scar on the upper valve (Pl. I, f. 10) ; this part of the shell is a deep green. The gill is of the same kind as that of the last species, but the filaments are typically very much finer and the number of intermediate ciliary rows is two and three, usually, instead of one and two, but may be more numerous in part or throughout (Pl. I, f. 3). Typical examples always show on the upper valve the peculiar striated sculpture of numerous crowded rows of minute radiating scales.

One form of this species to which I give the name of var. crassa, as I am unable to jdentify it with any of the numerous Anomiidæ which have been described, is so different that I at first thought it a distinct species both from shell and animal characters. It is very much thicker, particularly in the coarse upper valve: the surface occasionally shows traces of the typical squama sculpture, but is usually much encrusted and devoid of sculpture (Pl. I, f. 13-18). It is markedly convex from its habitat on the convex side of Pecten. Muscular scar much as in type, but the shell adductor is comparatively more dorsal, forming an anterior prolongation of the byssal scar (Pl. I, f. 11). Gill similar, but the separate filaments larger and coarser, and the intermediate ciliary rows are highly irregular, usually three and four or more (Pl. I, f. 4), while in typical squama these rows are regular. The hinge process on the lower valve is enormously developed, and the border of this valve has a wide green margin within. But these and other differences do not seem to me essential, and I have no doubt as to its being a variety of squama, modified by its more exposed habitat.

Genus HETERANOMIA, nov. Type, $A$. squamula, L. = A aculeata, Müller.

Anomiiform mollusca, in which the gill lamellæ have descending filaments only, each gill being therefore $\cap$ sbaped in section. The alimentary and circulatory systems show it to be allied to Anomia and Monia. The lateral asymmetry is strongly marked, so that the right gill is not much more than half the length of the other.

4. Squamula, L. $1758=A$. aculeata, Müller. There is no doubt that this is the Linnean species from the habitat on seaweed and

VOL. XV.-APRIL, 1922. 
crabs, and the locality, Swedish sea, where ephippium is not found. There is no distinction between the smooth and aculeate forms: I have taken wholly smooth, wholly aculeate and intermediate forms on the same Chlamys opercularis; nor can I find any essential difference in other varieties, such as cylindrica, Gmelin, from the arm of a crab Inachus. It is at once distinguished from all other Anomiidæ by the gills, which have no ascending lamellæ (Pl. I, f. 5). Two muscular scars in the upper valve, small adjacent but distinct (Pl. I, f. 12), not showing the radial furrows of Monia. The byssal plug is thin brown striate, as in Monia and quite different from that of Anomia. Jensen further points out (Danish Ingolf Exp., ii, 5, p. 1) that the notch of this species is small and oval and the umbo almost or entirely marginal, while the notch in patelliformis is large and triangular and the umbo always a little way off the margin.

\section{EXPLANATION OF PLATE I.}

Sections of Gill. (Diagrammatic. Dots indicate ciliary junctions.)

FIG. 1. Anomia ephippium. $\times 5$.

,2. Monia patelliformis. $\times 5$.

" 3. M. squama. $\times 5$.

" 4. M. squama var. crassa. $\times 5$.

" 5. Heteranomia squamula. Diagram of gill. $\times 5$.

" 6. H. squamula. Right side mantle removed, showing reduced gill.

$\times 3 / 2$.

„ 7. H. squamula. Left side, mantle removed. $\quad \times 3 / 2$.

Outlines of Muscular Scars in Left Valve.

Fig. 8. Anomia ephippium. Poole.

„9. Monia patelliformis. Firth of Forth.

„10. M. squama. Oban.

", 11. M. squama var. crassa. Eddystone.

„, 12. Heteranomia squamula. Brighton.

SHELls.

Figs. 13-18.-Monia squama var. crassa. Eddystone. 


\section{$2 \mathrm{BHL}$ Biodiversity Heritage Library}

Winckworth, Ronald. 1922. "NOTE ON THE BRITISH SPECIES OF ANOMIA." Proceedings of the Malacological Society of London 15, 32-34. https://doi.org/10.1093/oxfordjournals.mollus.a063764.

View This Item Online: https://www.biodiversitylibrary.org/item/95719

DOI: https://doi.org/10.1093/oxfordjournals.mollus.a063764

Permalink: https://www.biodiversitylibrary.org/partpdf/202511

\section{Holding Institution}

Smithsonian Libraries

\section{Sponsored by}

Smithsonian

\section{Copyright \& Reuse}

Copyright Status: Public domain. The BHL considers that this work is no longer under copyright protection.

This document was created from content at the Biodiversity Heritage Library, the world's largest open access digital library for biodiversity literature and archives. Visit BHL at https://www.biodiversitylibrary.org. 